\title{
Verhaalsbeslag op bitcoins
}

\author{
Tycbo de Graaf*
}

\begin{abstract}
1 Inleiding
Bitcoin is een cryptocurrency die waarde vertegenwoordigt. ${ }^{1}$ Bitcointransacties zijn gedecentraliseerd opgeslagen in een grootboek dat op alle computers staat die aan het bitcoinnetwerk deelnemen (de nodes), en dat met behulp van blockchaintechnologie door een consensusmechanisme (waarover later meer) wordt bijgehouden. Vergelijk het met betalingstransacties die zijn opgeslagen in een grootboek van een bank, alleen staat dat grootboek op de servers van de bank (gecentraliseerd) en wordt dat grootbroek door de bank bijgewerkt. Met behulp van het bitcoingrootboek kan worden bepaald welke transacties zijn verricht en hoeveel bitcoins op welke bitcoinrekening staan. Om bitcoins te kunnen overmaken van de ene naar de andere bitcoinrekening is een 64 tekens lange, automatisch gegenereerde privésleutel nodig (net zoals een pincode moet worden ingevoerd om met internetbankieren of een betalingsapp geld over te maken, alleen dan veel langer). ${ }^{2}$ Daarmee kan degene die een transactie met zijn privésleutel ondertekent aan de deelnemers van het bitcoinnetwerk laten blijken dat hij bitcoins op dat bitcoinadres mag en wil overmaken naar het bitcoinadres van een andere bitcoinrekening. Die privésleutel is vaak (1) afgedrukt op een stuk papier achter een kraslaag of een sticker (een zogeheten paper wallet ${ }^{3}$ ) of (2) opgeslagen op een speciaal daarvoor gemaakt device in de vorm van een USB-stick (een zogeheten hardware wallet ${ }^{4}$ ). De toegang tot de privésleutel is bij een paper wallet 'beveiligd' door de kraslaag of sticker (waardoor kan worden vastgesteld of iemand kennis heeft kunnen nemen van de privésleutel), bij de hardware wallet door een code (waardoor kan worden voorkomen dat een ander van die privésleutel kennis kan nemen). Deze bijdrage gaat uitsluitend over het leggen van
\end{abstract}

* Mr. dr. T.J. de Graaf is universitair docent burgerlijk recht aan de Universiteit Leiden.

1. Zie voor een simpele uitleg van bitcoin https://medium.freecodecamp. org/explain-bitcoin-like-im-five-73b4257ac833, en voor een grafische weergave www.upfolio.com/ultimate-bitcoin-guide. De werkelijkheid is complexer, zie https://en.wikipedia.org/wiki/Bitcoin en T.F.E. Tjong Tjin Tai, 'Juridische aspecten van blockchain en smart contracts', TPR 2017, afl. 2, p. 565-577. In deze bijdrage wordt uitgegaan van bitcoin. Er zijn zo'n 1600 cryptocurrencies (zie https://en.wikipedia.org/wiki/List_ of_cryptocurrencies), dus hoewel veel van het geschrevene vermoedelijk ook van toepassing zal zijn op andere cryptocurrencies, kan dit niet met zekerheid worden gezegd.

2. Zie https://en.bitcoin.it/wiki/Private_key, bijv. de daar genoemde privésleutel E9873D79C6D87DC0FB6A5778633389F4453213303DA61 F20BD67FC233AA33262.

3. Gemaakt met bijv. Wallet Generator, https://walletgenerator.net, of Bitcoin Paper Wallet, https://bitcoinpaperwallet.com.

4. Bijv. een Trezor, https://trezor.io, of Ledger, www.ledger.com/products/ ledger-nano-s?.r=2c06\&path=/products/ledger-nano-s\&tracker= walletsintro. conservatoir verhaalsbeslag op paper en hardware wallets die zich op het moment van beslaglegging in Nederland bevinden.

Een schuldeiser die een geldvordering heeft en zich, na het verkrijgen van een executoriale titel, op de bitcoins van zijn schuldenaar wil verhalen, moet feitelijk gezien de bitcoin paper wallet of hardware wallet zien te bemachtigen, en als sprake is van een hardware wallet ook de code waarmee de hardware wallet kan worden geopend. ${ }^{5}$ Daarmee heeft hij immers toegang tot de privésleutel waarmee hij bitcoins van de ene naar de andere bitcoinrekening kan overmaken. Juridisch gezien moet sprake zijn van een voor verhaal vatbaar goed. Daarvan is sprake als de bitcoin of het recht benodigd voor het bewerkstelligen van de overdracht als een vermogensrecht kan worden gekwalificeerd (waarover later meer). Ook moet bij voorkeur eerst conservatoir beslag worden gelegd om te voorkomen dat de schuldenaar door het uitbrengen van een dagvaarding gewaarschuwd wordt en, met gebruikmaking van een kopie van de privésleutel, zijn bitcoins verdonkeremaant voordat een veroordelend vonnis tegen hem ten uitvoer wordt gelegd.

Deze bijdrage gaat over de vraag hoe conservatoir verhaalsbeslag op bitcoins juridisch en feitelijk kan worden gelegd, en ook over hoe het conservatoir verhaalsbeslag, na het verkrijgen van een voor tenuitvoerlegging vatbare executoriale titel, overgaat in een executoriaal verhaalsbeslag en de schuldeiser wordt voldaan. Om deze vragen te beantwoorden maak ik gebruik van opvattingen uit twee eerdere artikelen. Ten eerste de opvatting dat paper en hardware wallets waardepapieren zijn. ${ }^{6}$ Deze goederenrechtelijke kwalificatie bepaalt op welke wijze conservatoir en executoriaal verhaalsbeslag op de wallets kan en moet worden gelegd, te weten volgens de bepalingen die

5. Ik ga ervan uit dat de privésleutel is opgeslagen op/in een paper of hardware wallet en dat door het bemachtigen van de wallet ook de daarin opgeslagen publieke sleutel en het bitcoinadres van die rekening worden bemachtigd. Voor deze bijdrage is het uitleggen van het onderscheid tussen privé- en publieke sleutels niet relevant. De geïnteresseerde lezer zij verwezen naar T.J. de Graaf, 'De kwalificatie van bitcoins', NJB 2019 , afl. 1, p. 6-18, par. 2 .

6. De Graaf 2019. Ik beantwoord de opgeworpen vragen voor zowel de paper alsook de hardware wallet in de hoop dat ik degenen die het een stap te ver vinden om een hardware wallet als een waardepapier aan te merken, in ieder geval ervan kan overtuigen dat een paper wallet als een waardepapier kan worden gekwalificeerd en beslag en executie plaats dient te vinden met inachtneming van de daarvoor geldende bepalingen. 
gelden voor beslag op en executie van waardepapieren. ${ }^{7}$ Ten tweede de samen met Bart Krans bedachte mogelijkheden een schuldenaar te dwingen om, na het verkrijgen van een executoriale titel, de code van zijn hardware wallet prijs te geven. ${ }^{8}$ Met deze bijdrage wordt de tussenruimte tussen beide artikelen opgevuld: de fase tussen het kwalificeren van bitcoin(rechten) en het executeren daarvan, dus de fase waarin er conservatoir en vervolgens executoriaal beslag wordt gelegd.

\section{Paper en hardware wallets zijn waardepapieren}

Zoals gezegd vind ik dat paper en hardware wallets waardepapieren zijn. ${ }^{9}$ Een waardepapier belichaamt één of meer vorderingen. Zo belichaamt een cognossement het recht op aflevering van lading die over zee van A naar B wordt vervoerd. Daarnaast legitimeert het cognossement de houder ervan als gerechtigde op die aflevering en kan door bezitsverschaffing van het cognossement de lading vóór aflevering worden geleverd (art. 8:417 jo. art. 3:93 jo. art. 3:90 BW). ${ }^{10}$ Om te kunnen concluderen dat een paper en hardware wallet ook waardepapieren zijn en vast te stellen welke rechten daarin zijn belichaamd, zal ik drie stappen zetten. Eerst leg ik uit hoe A technisch gezien een bitcoin van zijn eigen bitcoinrekening naar die van B overmaakt. ${ }^{11}$ Daaruit zal blijken welke rechten A bij het overmaken naar B vanuit verbintenisrechtelijke optiek uitoefent en ten opzichte van wie. En daar blijkt weer

7. Zie voor andere, vaak minder optimistische opvattingen over de mogelijkheden beslag te leggen op bitcoins en deze te executeren, M. Bernardt \& J.D. van Vlastuin, 'De executie van bitcoins', De Gerechtsdeurwaarder 2015, afl. 1, p. 26, die betogen dat art. 444 lid 2 Rv kan worden toegepast om binnen te dringen in de bestanden van de schuldenaar (maar waarbij ik me afvraag of een hacker wel door de beveiliging van een hardware wallet heen kan breken); M. van Ingen \& W. Smits, 'Beslag op bitcoin: (praktisch) onmogelijk', BER 2018, afl. 2, p. 21, die geneigd zijn te concluderen dat beslag op bitcoins naar huidig recht niet mogelijk is, en menen dat als de stap wordt gemaakt bitcoins te kwalificeren als (vermogens)recht, beslag op grond van art. $474 \mathrm{bb} \mathrm{Rv}$ op grote praktische moeilijkheden stuit; en J.W.A. Biemans, 'Beslag op en executie van domeinnaamrechten en bitcoins', in: S.J.W. van der Putten \& M.R. van Zanten (red.), Compendium Beslag-en executierecht, Den Haag: Sdu Uitgevers 2018, p. 578, die bepleit dat Rv moet worden aangevuld met maatwerk met betrekking tot het in beslag nemen van cryptocurrencies, waarbij wettelijk verankerd zou moeten worden 'de bevoegdheid van de beslaglegger om zich toegang te verschaffen tot de digitale gegevens en de hardware (...) om grip te krijgen op deze verhaalsobjecten'.

8. T.J. de Graaf \& H.B. Krans, 'Verhaal op bitcoins door gedwongen medewerking van de schuldenaar', WPNR 2018/7217, p. 940-945.

9. Andere opvattingen, die ik vanwege de lengte van deze bijdrage niet bespreek, gaan er veelal van uit dat bitcoins (absolute) vermogensrechten zijn. De aanhangers verschillen van mening over de vraag of die vermogensrechten in ons goederenrechtelijk systeem kunnen worden ingepast. Tweehuysen vindt van wel (V. Tweehuysen, 'Goederenrechtelijk puzzelen met bitcoins', $A A$ 2018, p. 602-610); Rank en Mijnssen hebben daar moeite mee (W.A.K. Rank, 'Bitcoins: civielrechtelijke en toezichtrechtelijke aspecten', in: R.A. Wolf e.a., Bitcoins. Civiele en fiscale aspecten in beeld, Deventer: Wolters Kluwer 2015, p. 36-37 respectievelijk F.H.J. Mijnssen, Verbintenissen tot betaling van een geldsom (Mon. BW nr. B39), Deventer: Wolters Kluwer 2017/1.6).

10. M.H. Claringbould, Het schip en zijn cognossementen (oratie Leiden), Deventer: Kluwer/W.E.J. Tjeenk Willink 1996, p. 1 en 28-31.

11. Zie voor een beschrijving van het overmaken van bitcoins A.M. Antonopoulos, Mastering bitcoin. Programming the open blockchain, Sebastopol, CA: O’Reilly 2017, p. 8-14 en 212-267. uit welke rechten vanuit goederenrechtelijk perspectief aan toonder worden gesteld en aldus in een waardepapier (zijnde de paper of hardware wallet) worden belichaamd.

Technisch gezien werkt het overmaken van bitcoins als volgt. Zodra A een transactie in zijn bitcoinsoftware met zijn privésleutel ondertekent, zet hij de zogeheten miners in het bitcoinnetwerk aan het werk. Miners ${ }^{12}$ zijn computers waarop bitcoinsoftware ${ }^{13}$ draait en die volledig automatisch deelnemen aan een wedstrijd (speed competition) om als eerste (1) te verifierren of een aantal transacties, verzameld in een candidate block en waaronder de transactie van A naar B, juist is (denk bij het overmaken van giraal geld aan clearing), en (2) om misbruik te voorkomen, een daarmee verband houdende, ingewikkelde cryptografische puzzel op te lossen. Het werk van de winnende miner wordt vervolgens met behulp van software ${ }^{14}$ automatisch gecontroleerd door alle computers die aan het bitcoinnetwerk deelnemen (de nodes, in een quality competition). Zodra minimaal 51 procent van de nodes het eens is dat de winnende miner zijn werk goed heeft gedaan, wordt zogeheten consensus bereikt. Daardoor geldt de transactie als bevestigd (confirmed) en wordt het candidate block als block aan de blockchain toegevoegd en daarmee opgeslagen in het grootboek dat over alle nodes wordt verspreid, en dus uiteindelijk op iedere node gedecentraliseerd wordt opgeslagen. ${ }^{15}$ De winnende miner wiens werk aldus goed is bevonden, wordt daarvoor beloond met bitcoins die voor het eerst door het systeem worden gecreëerd/gedolven/gemined (het block reward) en met bitcoins die door gebruiker A worden betaald (transactiekosten).

Verbintenisrechtelijk is het bitcoinnetwerk aan te merken als een meerpartijenovereenkomst waarin door de techniek bepaalde (en daarmee impliciete) derdenbedingen zijn opgenomen ten gunste van iedere gebruiker (in ons voorbeeld: A en $\mathrm{B}$ ), iedere miner en iedere node die in de betreffende hoe-

12. In de praktijk werken miners samen in zogeheten mining pools en delen de eventuele winst die zij ontvangen (het block reward, zie hierna) als hun pool wint. Zie voor een overzicht van mining pools en hun 'marktaandeel': www.blockchain.com/pools.

13. Zoals CGMiner, https://en.bitcoin.it/wiki/CGMiner, of BFGMiner, http://bfgminer.org.

14. Zoals BitcoinCore, https://bitcoincore.org.

15. Het feit dat er vermoedelijk zo'n 1 miljoen individuele mensen minen (www.buybitcoinworldwide.com/how-many-bitcoins-are-there/), minimaal 51 procent van de nodes een transactie moet goedkeuren, er meer dan 10.000 nodes zijn (https://bitnodes.earn.com) en de miners en nodes zich in allerlei verschillende landen bevinden, heeft overigens tot gevolg dat het praktisch onmogelijk is om (door middel van een executoriaal derdenbeslag en daaropvolgende executie) de miners en nodes te dwingen om een transactie al dan niet te verrichten. De gepropageerde waardepapierenconstructie werkt in zoverre beter, dat daarmee op de crediteuren- in plaats van debiteurenkant wordt gefocust. Overigens spoort het feitelijk niet kunnen leggen van derdenbeslag met het ontwerp van een blockchainapplicatie zoals bitcoin: het praktisch onmogelijk maken voor derden om invloed uit te oefenen op transacties door slechts een beperkt aantal deelnemers juridisch of feitelijk aan te vallen of te hacken. Zie voor een technische uitleg van forks, waarmee in uitzonderlijke omstandigheden en met veel mitsen, maren en consensus kan worden ingegrepen: www.coindesk.com/short-guide-bitcoin-forksexplained/, en voor een uitleg van de hard fork bij de The DAO-hack T.J. de Graaf, 'Van oud naar nieuw: van internet naar smart contracts en van mensen naar code (II, slot)', WPNR 2018/7200, p. 525-530. 
danigheid aan het bitcoinnetwerk wil deelnemen (tezamen: de deelnemers). ${ }^{16}$ Zodra zo'n deelnemer voor het eerst deelneemt aan het bitcoinnetwerk, aanvaardt hij het derdenbeding en wordt hij partij bij de meerpartijenovereenkomst (art. 6:253 lid 1 jo. lid 3 jo. art. 3:37 lid 1 BW). De inhoud van de uit die meerpartijenovereenkomst voortspruitende rechten en verplichtingen is afhankelijk van de hoedanigheid van de betreffende deelnemer. Een miner verplicht zich ten opzichte van degene die de juiste privésleutel presenteert (in ons voorbeeld: gebruiker A) om deel te nemen aan de speed competition, en dus de transactie van A naar B te verifiëren en de daarmee verband houdende cryptografische puzzel op te lossen. Iedere node verplicht zich ten opzichte van gebruiker A om deel te nemen aan de quality competition, en dus het werk van de winnende miner te controleren. De rechten van de gebruikers ten opzichte van de miners en nodes om hun verificatierespectievelijk controlewerkzaamheden te verrichten, zijn overdraagbare vorderingen (en dus voor verhaal vatbare goederen), welke werkzaamheden verricht moeten worden om bitcoins over te kunnen maken. Deze noem ik bitcoinvorderingen. ${ }^{17} \mathrm{Bij}$ het uitvoeren van hun werkzaamheden controleren miners (en dus ook de nodes die de winnende miner controleren) alleen of de gepresenteerde privésleutel gekoppeld is aan het bitcoinadres van waaruit bitcoins worden overgemaakt. Niet wie daarachter schuilgaat. Het makkt, met andere woorden, voor de miners en nodes niet uit of de privésleutel wordt gepresenteerd door degene die de bitcoins gedolven heeft, iemand aan wie hij zijn privésleutel heeft gegeven of iemand die de sleutel gestolen heeft. Overigens worden de werkzaamheden van de miners en nodes door hen volledig automatisch uitgevoerd, waardoor in de praktijk vragen met betrekking tot niet-nakoming niet rijzen.

Goederenrechtelijk worden bitcoinvorderingen aan toonder gesteld op het moment dat de betreffende bitcoin voor het eerst op een bitcoinrekening wordt bijgeschreven, en wel aan de toonder van de privésleutel die hoort bij het bitcoinadres waar de bitcoin op staat. De privésleutel staat op zijn beurt op de paper of hardware wallet, en daarmee is een waardepapier gecreëerd, meer specifiek een toonderpapier. ${ }^{18}$ De wallet belichaamt de bitcoinvorderingen met betrekking tot de bitcoins die op de bitcoinrekening staan waarvan de privésleutel in de

16. Men kan overigens tegelijkertijd in verschillende hoedanigheden aan het bitcoinnetwerk deelnemen. Miners zijn bijv. ook vaak nodes.

17. Vgl. T.F.E. Tjong Tjin Tai, 'De blockchain als alternatief voor de notariele praktijk', in: F.W.J.M. Schols \& B.C.M. Waaijer (red.), Financiële zorgplicht van de notaris (preadviezen KNB), Den Haag: Sdu Uitgevers 2018, p. 123. Hij schrijft: 'Misschien is het wel mogelijk om de controlemogelijkheden of potentiële aanspraak op een tegoed in bitcoin te beschouwen als een vorderingsrecht, waar men bij de partij die de aanspraak heeft derdenbeslag zou kunnen leggen.'

18. Zo'n toonderpapier kan worden gecreëerd, want Nederland kent een open stelsel van waardepapierenrecht, zie R. Zwitser, Order- en toonderpapieren (Mon. BW nr. A28), Deventer: Wolters Kluwer 2017, nrs. 4 en 5, onder verwijzing, voor wat betreft het open stelsel, naar HR 19 april 2002, ECLI:NL:HR:2002:AE1683, NJ 2002/456, m.nt. M.M. Mendel (Zürich/Lebosch). wallet is opgeslagen. De paper en hardware ${ }^{19}$ wallet zijn dus waardepapieren, en wel toonderpapieren.

\section{Conservatoir verhaalsbeslag op de wallet}

$\mathrm{Nu}$ is vastgesteld dat de bitcoinvorderingen belichaamd zijn in een paper of hardware wallet en die wallet kwalificeert als een waardepapier, zijnde een toonderpapier, is de volgende stap het leggen van conservatoir verhaalsbeslag op dat waardepapier, waarvan ik aanneem dat het in handen van de schuldenaar is. Weet de schuldeiser alleen dat de schuldenaar over paper of hardware wallets beschikt, maar niet om welke specifieke wallets het gaat, dan lijkt mij een algemene omschrijving daarvan voldoende. Slechts in een aantal artikelen bepaalt de wet met zoveel woorden dat het beslagobject moet worden omschreven, zie bijvoorbeeld art. 711 lid $3 \mathrm{Rv}$ ten aanzien van de zogeheten art. $474 \mathrm{bb}$-rechten. ${ }^{20}$ De artikelen die van toepassing zijn op beslag op waardepapieren bevatten niet zo'n voorschrift en dus kan, a contrario, met een algemene omschrijving worden volstaan of, zoals F.M.J. Jansen het uitdrukt ten aanzien van het leggen van conservatoir beslag op roerende zaken in handen van de schuldenaar:

'Het presidiaal verlof wordt gevraagd en verleend voor een beslag op roerende zaken van de debiteur, welke eerst door het exploot van beslag worden geïndividualiseerd (cfr. art. 443); niettemin blijft de bevoegdheid van de arrestant bestaan om verlof te vragen voor beslag op bepaalde in het rekest omschreven zaken.' 21

Volgens art. 702 lid 1 jo. art. 711-713 Rv wordt conservatoir verhaalsbeslag op een toonderpapier in handen van de schuldenaar gelegd met overeenkomstige toepassing van de voorschriften geldend voor het leggen van executoriaal beslag tot verhaal van een geldvordering op een toonderpapier. Volgens art. 474a lid $1 \mathrm{Rv}$ moet beslag worden gelegd op het papier en daarop zijn 'van overeenkomstige toepassing, tenzij uit de betreffende bepaling in verband met de aard van het recht anders volgt': (1) art. 474a- 474bb $\mathrm{Rv}$ en (2) het in art. 439-474 Rv bepaalde over beslag op zaken. Art. 700 lid 1 jo. lid 2 Rv bepaalt dat voor het leggen van zo'n conservatoir verhaalsbeslag beslagverlof moet worden verzocht bij de voorzieningenrechter van de rechtbank van het arrondissement waar '[zich] een of meer van de betrokken zaken bevinden, dan wel, indien het beslag niet op zaken betrekking heeft, de schuldenaar (...) onder wie het beslag gelegd wordt, woonplaats heeft'. Om deze relatieve bevoegdheid te bepalen zijn

19. Dat een hardware wallet niet van papier is, is geen probleem omdat voldaan is aan het in art. 6:227a BW bepaalde. Zie daarover, en over andere tegenwerpingen, uitgebreider De Graaf 2019, p. 15-17.

20. Vgl. Gieske, in: T\&C Burgerlijke Rechtsvordering, art. $700 \mathrm{Rv}$, aant. 3.e.

21. F.M.J. Jansen, Executie- en beslagrecht, Zwolle: W.E.J. Tjeenk Willink 1990, p. 326. Zie ook en wellicht anders: W.H. van Boom, Verhaal, uitwinning en rangorde. Hoofdlijnen materieel beslag-en faillissementsrecht, Den Haag: Boom juridisch 2018, nr. 3.3, onder verwijzing naar HR 30 maart 2001, ECLI:NL:HR:2001:AB0805, NJ 2002/380 (LISV) Grifhorst), die verhaalsbeslag omschrijft als een harpoen en geen sleepnet. 
twee redeneringen denkbaar. De eerste is, zoals de beslagsyllabus het uitdrukt, dat ' $[\mathrm{h}]$ et beslag op rechten aan toonder of order geschiedt conform het beslag op roerende zaken. Het waardepapier wordt in beslag genomen', en dat dus de voorzieningenrechter van het arrondissement waar de paper of hardware wallet zich fysiek bevindt relatief bevoegd is. ${ }^{22}$ De tweede is dat verlof wordt gevraagd voor het leggen van beslag op bitcoinvorderingen belichaamd in het waardepapier, dat die vorderingen geen zaken zijn, dat dus de voorzieningenrechter in de woonplaats van de schuldenaar relatief bevoegd is, en dat vervolgens het beslag zelf wordt gelegd conform het beslag op roerende zaken. Vooralsnog lijkt me de eerste optie te verkiezen boven de tweede, omdat dat beter past in het systeem van de wet.

In het beslagrekest waarmee de schuldeiser verlof vraagt om conservatoir beslag te leggen, moet hij, naast de aanduiding van het beslagobject (zie hierboven) en het voor het overige gebruikelijke, ${ }^{23}$ aanvoeren waarom er gegronde vrees voor verduistering bestaat (art. 711 lid $1 \mathrm{Rv}$ ). Die eis komt erop neer dat de verzoeker ten opzichte van de voorzieningenrechter aannemelijk moet maken dat wanneer het beslag niet nu wordt gelegd, later 'bij eventueele toewijzing van de vordering van den schuldeischer [in de hoofdzaak; TG] het slagen van de executie op het vermogen van den schuldenaar in gevaar zal komen, weshalve reeds thans een conservatoir beslag noodzakelijk is te achten'. ${ }^{24}$ Aan het aannemelijk maken van die vrees worden in de praktijk geen hoge eisen gesteld. ${ }^{25}$ Voor het kunnen beslaan van een paper of hardware wallet moet die vrees dus ook worden gesteld, zij het dat het mijns inziens voldoende zou moeten zijn om in het beslagrekest het volgende uit te leggen. Ten eerste dat met gebruikmaking van de in die wallet opgeslagen privésleutel de betreffende bitcoins in enkele seconden kunnen worden overgemaakt naar een andere bitcoinrekening (waarvan de privésleutel zich op een nietbekende plek in binnen- of buitenland kan bevinden), waardoor als geen conservatoir beslag wordt gelegd voordat een dagvaarding wordt betekend, executie van een te zijner tijd verkregen veroordelend vonnis in gevaar komt, of zelfs illusoir zal zijn. Ten tweede dat de schuldenaar zijn privésleutel zeer wel in meerdere wallets kan hebben opgeslagen en eenzelfde tweede of derde privésleutel zou kunnen gebruiken om de bitcoins alsnog weg te sluizen. Anders dan bij de uitgifte van bijvoorbeeld meerdere exemplaren van een cognossement waar-

22. Beslagsyllabus, augustus 2018 , p. 28

23. Zie art. 21,278 en $700 \mathrm{Rv}$ en over art. $21 \mathrm{Rv}$ HR 25 maart 2011 , ECLI:NL:HR:2011:BO9675, m.nt. H.J. Snijders (waarheidsplicht). Zie ook Beslagsyllabus, augustus 2018, A. Voorwaarden conservatoir beslag, p. 8-14.

24. HR 2 april 1936, NJ 1936/758 (Fox/Dominium).

25. Van den Heuvel, in: GS Burgerlijke rechtsvordering, art. $700 \mathrm{Rv}$, aant. 4 (bijgewerkt 15 mei 2014), onder verwijzing naar L.P. Broekveldt, Derdenbeslag (diss. Leiden), Deventer: Kluwer 2003, nr. 393. Zie ook H.G. Punt, Memo beslagrecht 2018, Deventer: Wolters Kluwer 2018, p. 143-144: 'De vrees houdt in dat er een redelijke verwachting bestaat dat de goederen waarop het beslag gelegd zal worden, door de schuldenaar (...) aan het verhaal zal worden onttrokken.' op aangegeven wordt hoeveel exemplaren zijn afgegeven, ${ }^{26}$ is aan een wallet niet te zien of er meerdere wallets zijn waarin dezelfde privésleutel is opgeslagen.

\subsection{Overmaken naar een andere bitcoinrekening om wegsluizen te voorkomen}

Dat brengt mij tot de volgende vraag: hoe kan worden voorkomen dat na het leggen van conservatoir beslag de beslagdebiteur, met gebruikmaking van zo'n tweede of derde sleutel, de bitcoins wegsluist voordat een executoriale titel wordt verkregen en tot executie wordt overgegaan? Voordat ik die vraag beantwoord, maak ik een uitstapje naar het in beslag nemen van contant geld. Als de deurwaarder bij de inbeslagneming 'gereed geld' en 'geldswaarde hebbend papier' aantreft, is hij gehouden 'dat aan een door hem aan te wijzen financiële onderneming die ingevolge de Wet op het financieel toezicht in Nederland het bedrijf van bank mag uitoefenen of door een zodanige financiële onderneming gegarandeerd effectenbewaarbedrijf of aan de Nederlandsche Bank N.V.' (art. 711 jo. art. 712 jo. art. $445 \mathrm{Rv}$ ) in gerechtelijke bewaring te geven 'ten name van de deurwaarder onder vermelding van het beslag, van de executant en van de geëxecuteerde'. Vervolgens stort de deurwaarder dat geld bij een bank of bij De Nederlandsche Bank (DNB) op een speciale of generale kwaliteitsrekening en bedingt hij 'een marktconforme rente (...) in elk geval wanneer het gaat om een netto-executieopbrengst die een aanzienlijk bedrag beloopt terwijl voorzienbaar is dat dit bedrag niet spoedig aan de rechthebbende(n) kan worden uitgekeerd'. ${ }^{27} \mathrm{Bij}$ inbeslagneming van een toonderpapier geeft de deurwaarder het papier in bewaring bij een bank of DNB (hierna: bank). De bank registreert vervolgens het unieke nummer van het toonderpapier en bergt het op in een kluis. Het doel van deze vormen van gerechtelijke bewaring is het beslagobject aan de beslaglegger en beslagdebiteur te onttrekken en niet tot het vermogen van de deurwaarder te laten behoren, zodat het veilig is gesteld ten gunste van de rechthebbenden. ${ }^{28}$

26. Zie art. 8:413 BW en Zwitser 2017, nr. 16. Zie voor wissels art. 163 WvK en voor cheques art. $226 \mathrm{WvK}$.

27. Van Mierlo, in: GS Burgerlijke rechtsvordering, art. $445 \mathrm{Rv}$, aant. 2 (bijgewerkt 1 januari 2007), onder verwijzing naar HR 12 januari 2001, ECLI:NL:PHR:2001:AA9441, NJ 2002/371, m.nt. H.J. Snijders (Koren/Tekstra) voor wat betreft de door gebruikmaking van een kwaliteitsrekening beoogde vermogens(af)scheiding en HR 29 januari 2010, ECLI:NL:HR:2010:BK3571, NJ 2011/236, m.nt. A.I.M. van Mierlo (Staat/Lehman Brothers c.s.) voor wat betreft de rente. Zie verder J.S. Evers, 'Beslag op contant geld', in: S.J.W. van der Putten \& M.R. van Zanten (red.), Compendium Beslag- en executierecht, Den Haag: Sdu Uitgevers 2018, p. 511-518.

28. Van Mierlo, in: GS Burgerlijke rechtsvordering, art. $445 \mathrm{Rv}$, aant. 2 (bijgewerkt 1 januari 2007). 
Aangezien paper en hardware wallets waardepapieren zijn en een geldwaarde hebben, ${ }^{29}$ dient de deurwaarder de paper of hardware wallet dus in bewaring te geven aan een bank, met als doel deze te onttrekken aan de beslaglegger en de beslagdebiteur en veilig te stellen ten gunste van de rechthebbenden. De hamvraag is hoe de deurwaarder dat doel in de praktijk kan bereiken. Mijns inziens kan dat alleen door de bitcoins zo snel mogelijk over te maken op een door een bank geopende bitcoinrekening met gebruikmaking van de op de paper of hardware wallet afgedrukte respectievelijk opgeslagen privésleutel. Zodra de bitcoins zijn overgemaakt op de door de bank geopende nieuwe bitcoinrekening, komt het conservatoir beslag op de oorspronkelijke paper of hardware wallet door substitutie automatisch te rusten op de nieuwe paper of hardware wallet (art. 711 jo. art. 712 jo. art. 455a Rv), dus op de wallet van de bank waarin de privésleutel van de nieuwe bitcoinrekening is opgeborgen.

Een goede timing is bij dit alles onontbeerlijk. De deurwaarder zou eigenlijk vóór beslaglegging door de betreffende bank een bitcoinrekening moeten laten openen om, zodra hij de privésleutel van de beslagdebiteur bemachtigt, ter plekke de bitcoins naar die rekening over te maken. ${ }^{30}$ Alleen zo kan de deurwaarder feitelijk ${ }^{31}$ voorkomen dat de beslagdebiteur een door hem mogelijkerwijs ook elders opgeslagen privésleutel gebruikt om de bitcoins weg te sluizen kort nadat de deurwaarder de plaats van inbeslagneming verlaat. Sterker nog, de deurwaarder is daartoe verplicht. Anders geeft de deurwaarder een paper of hardware wallet in bewaring aan een bank die die wallet als het ware in een kluis opbergt, terwijl hij weet, althans behoort te weten dat er een gerede kans is dat de beslagdebiteur over een kopie van de sleutel van de kluis

29. Daarbij is overigens wel de vraag of de daarin opgenomen privésleutel toegang geeft tot een bitcoinrekening waarop (nog) bitcoins staan. Die vraag laat zich echter net zo stellen bij het leggen van conservatoir beslag op een cognossement ten aanzien waarvan meerdere exemplaren zijn afgegeven. Ook daar rijst de vraag of het cognossement nog wel geldwaarde heeft. Als een ander exemplaar van dat cognossement ten tijde van de beslaglegging al aan de vervoerder is gepresenteerd en die de lading heeft meegegeven, dan heeft het inbeslaggenomen exemplaar geen waarde (meer).

30. Een zodanige bitcoinrekening lijkt me geen (afgescheiden) kwaliteitsrekening waarop schuldenaren van de deurwaarder geen verhaal kunnen nemen ex art. 19 GDW. Dat artikel spreekt immers over 'gelden' en bitcoins worden niet gerekend tot gangbaar geld in de zin van art. 6:112 BW, zie Rank 2015, p. 26-39; R. Koolhoven, 'Over geldvoorwerpschulden en de betaling met Bitcoins', in: R.J.C. Flach e.a. (red.), Dwingend privaatrecht op maat, Den Haag: Boom Juridische uitgevers 2015, p. 85-100; Mijnssen 2017/1.6. Zie ook B. Bierens, 'Veranderend betaalgedrag vanuit een juridisch perspectief. Kan het contant geld al worden afgeschaft?', NJB 2018, afl. 19, p. 1348, die meent dat bitcoin op een elektronisch equivalent van contant geld lijkt en de overdracht van bitcoin gelijkenis vertoont met een girale betaling.

31. Juridisch heeft het beslag blokkerende werking en blijft het kleven, zie art. 702 lid 1 jo. art. 711 jo. art. 712 jo. art. 453a Rv en HR 20 februari 2009, ECLI:NL:HR:2009:BG7729, NJ 2009/376, m.nt. A.I.M. van Mierlo (Ontvanger/De Jong). Ook staat op het onttrekken van een goed aan beslag of gerechtelijke bewaring een gevangenisstraf van maximaal vier jaar of een geldboete van de vierde categorie (art. 198 lid $1 \mathrm{Sr}$ ). Gelet op de snelheid van overboeken en de mogelijkheden voor de verkrijger anoniem te blijven, zal de schuldeiser daar in de praktijk niet zo heel veel aan hebben. beschikt waarmee hij onopgemerkt de inhoud kan ontvreemden.

Steun voor die opvatting kan ook worden gevonden in art. $446 \mathrm{Rv}$, dat de deurwaarder verplicht andere zaken dan gereed geld of geldswaarde hebbend papier bij een bewaarder in gerechtelijke bewaring te geven 'indien dit voor het behoud van deze zaken redelijkerwijze noodzakelijk is'. Deze ratio lijkt dezelfde als die van art. $445 \mathrm{Rv}$ : voor het behoud van de waarde van een toonderpapier, die niet zit in de waarde van het papier maar in de rechten die kunnen worden uitgeoefend door het tonen van dat papier, is het noodzakelijk ervoor te zorgen dat die rechten uitgeoefend kunnen blijven worden, zodat die rechten ook iets opbrengen als het waardepapier te zijner tijd in het kader van de executie wordt verkocht. Dat kan alleen door ervoor te zorgen dat de beslagdebiteur die rechten niet meer kan uitoefenen na beslaglegging, en dat kan, op zijn beurt, alleen maar door de privésleutel te gebruiken om de bitcoins naar een andere bitcoinrekening over te maken, in dit geval die van de bank.

\subsection{Beslagdebiteur dwingen zijn code prijs te geven}

Een en ander veronderstelt natuurlijk wel dat de deurwaarder over de privésleutel beschikt waarmee hij de bitcoins naar een andere bitcoinrekening kan overmaken. Bij de paper wallet heeft de deurwaarder die. Het enige dat hij daarvoor hoeft te doen, is de kraslaag te verwijderen. Bij een hardware wallet is dat anders. Aannemende dat de beslagdebiteur hem die code niet vrijwillig geeft en ervan uitgaande dat de code niet, althans niet tegen redelijke kosten kan worden gekraakt, moet de deurwaarder een manier zien te vinden om de beslagdebiteur te dwingen de code prijs te geven. In het kader van het executoriaal verhaalsbeslag achten Bart Krans en ik een aantal mogelijkheden kansrijk om dat voor elkaar te krijgen. Ten eerste verwezen wij naar de parlementaire geschiedenis ten aanzien van art. $444 \mathrm{Rv}$, waar de minister liet weten: 'De commissie heeft zich bij dit artikel afgevraagd in hoeverre de geëxecuteerde en eventuele derden verplicht zijn tot medewerking aan de tenuitvoerlegging', waarop de minister antwoordde dat ' (...) moet worden aangenomen dat deze voortvloeit uit zijn verplichting om aan de executoriale titel te voldoen, zoals deze door de rechter die de veroordeling uitsprak, is vastgesteld'. ${ }^{32}$ Vervolgens refereerden we aan Tripels/Masson, waarin de Hoge Raad oordeelde dat de schuldenaar die aan een gerechtelijke uitspraak dient te voldoen, gehouden is inlichtingen (...) omtrent voor verhaal vatbare goederen te verschaffen' (r.o. 4.1). ${ }^{33}$ Daarbij verwees hij naar art. $475 \mathrm{~g} \mathrm{Rv}$ en, volgens annotator Vranken, impliciet naar art. 6:2 en 6:248 BW. Weliswaar bood die formulering in die zaak niet genoeg ruimte aan de schuldeiser om de schuldenaar rekening en verantwoording te laten afleggen met betrekking tot

32. Parl. Gesch. Wijziging Rv e.a.w. (Inv. 3, 5 en 6), p. 111 (MvA II Inv.).

33. HR 20 september 1991, ECLI:NL:HR:1991:ZC0338, NJ 1992/552, m.nt. J.B.M. Vranken (Tripels/Masson), waarover M.A.J.G. Janssen \& J. Nijenhuis, 'Verplicht schuldenaar in executoriale fase tot verschaffen van informatie over vermogenspositie', in: S.J.W. van der Putten \& M.R. van Zanten (red.), Compendium Beslag-en executierecht, Den Haag: Sdu Uitgevers 2018, p. 187-208. 
zijn financiële staat, maar wellicht wel om de schuldenaar in de beschreven situatie van het bitcoinbeslag te verplichten de code of privésleutel te verstrekken. ${ }^{34}$ En omdat de aan ons executierecht ten grondslag liggende premisse 'wat niet goedschiks kan, kan kwaadschiks', anders dan bijvoorbeeld bij het openbreken van een kluis, bij de executie van bitcoins niet opgaat, vonden wij het aanvaardbaar om de schuldenaar te verplichten zijn code prijs te geven. ${ }^{35}$

Ik vind het verdedigbaar dat deze lijn wordt doorgetrokken naar het conservatoir verhaalsbeslag. Daarbij realiseer ik me dat de hiervoor aangedragen grondslagen beperkt zijn tot de executoriale beslagfase, de heersende leer is dat die grondslagen niet ook in de conservatoire beslagfase mogen worden gebruikt, en dat in de conservatoire beslagfase meer terughoudendheid gepast is dan in de executoriale. Toch vind ik deze argumenten van onvoldoende gewicht in dit specifieke geval, gelet op de bijzondere aard van dit beslag. De reden is simpel: als we het erover eens zijn dat verhaal op bitcoins in de executiefase mogelijk moet zijn, dan moet het ook mogelijk zijn conserverende maatregelen te treffen om ervoor te zorgen dat het betreffende vermogensbestanddeel juridisch, ${ }^{36}$ maar vooral ook feitelijk 'bevroren' kan worden, zodat het uiteindelijk geëxecuteerd kan worden. Wie A zegt, moet ook B zeggen. De wet voorziet in mogelijkheden roerende zaken en waardepapieren in de conservatoire beslagfase in gerechtelijke bewaring te laten nemen, met name om in feitelijke zin te voorkomen dat ze aan het beslag worden onttrokken. Daar waar de schuldenaar niet aan een inbewaarneming wil meewerken, veronderstelt de wet dat er altijd mogelijkheden zijn dat te bewerkstelligen zonder die medewerking, en wel met hulp van de sterke arm, zie art. 702 lid 1 of 711 en 712 jo. art. 444-444b Rv. Bij bitcoins helpt de sterke arm niet en dus moet teruggevallen worden op het afdwingen van de medewerkingsverplichting van de schuldenaar teneinde het conservatoir beslag zinvol te doen zijn.

Ten aanzien van de conservatoire fase kan ten slotte nog worden gewezen op het Molenbeek-arrest. ${ }^{37}$ Een van de redenen, zo niet de belangrijkste reden, voor de Hoge Raad om het bewijsbeslag in IE-zaken naar niet-IE-zaken door te trekken, is om de beslaglegger een middel in handen te geven waarmee voorkomen kan worden dat het betrokken bewijs anders verloren gaat. Die ratio maakt zelfs dat als er redelijke gronden

34. Aldus ook M. van Ingen \& W. Smits, 'Beslag op bitcoin: (praktisch) onmogelijk', BER 2018, afl. 2, p. 21.

35. Ter verdere onderbouwing refereerden we nog naar een andere premisse van ons executierecht, te weten 'de wenselijkheid dat voor alle vermogensbestanddelen die zich voor verhaal lenen, een behoorlijke regeling omtrent de uitwinning daarvan behoort te bestaan', Parl. Gesch. Wijziging Rv e.a.w. (Inv. 3, 5 en 6), p. 79 (MvT Inv.).

36. Zie voetnoot 31 .

37. HR 13 september 2013, ECLI:NL:HR:2013:BZ9958, NJ 2015/455, m.nt. H.B. Krans (Molenbeek Invest/Begeer), waarover W.F. Dammers $\&$ N. Vrugt, 'Bewijsbeslag en het inzagerecht op bescheiden en ander bewijsmateriaal "elders dan op de aangetroffen gegevensdrager", zoals in de cloud', in: S.J.W. van der Putten \& M.R. van Zanten (red.), Compendium Beslag- en executierecht, Den Haag: Sdu Uitgevers 2018, p. 675-690. zijn om te vermoeden dat de onder het beslagverlof vallende bestanden zich elders bevinden (bijvoorbeeld in de cloud), de beslagdebiteur die bestanden voor de deurwaarder toegankelijk moet maken. De grondslag voor die medewerkingsplicht schuilt in het door de voorzieningenrechter gegeven beslagverlof:

'De rechterlijke toestemming tot beslaglegging omvat in dit soort gevallen immers uit haar aard mede een tot de beslagene of de derde gericht bevel om de noodzakelijke medewerking te verlenen aan de beslaglegging omdat die toestemming anders zinloos zou zijn.' (r.o. 3.9.10)

Die medewerkingsverplichting gaat overigens niet zo ver dat de beslagdebiteur de door de deurwaarder in beslag genomen bestanden moet ontsleutelen (r.o. 3.9.9). Dat is echter geen argument om in het door mij geschetste geval aan te nemen dat de beslagdebiteur niet gehouden is zijn code prijs te geven waarmee de in conservatoir beslag genomen hardware wallet kan worden ontsleuteld. Integendeel. De reden waarom de Hoge Raad in de Molenbeek-zaak oordeelde dat de medewerkingsplicht niet ook een ontsleutelingsplicht behelsde, was omdat het doel van het bewijsbeslag is om ervoor te zorgen dat bewijsmiddelen niet verloren gaan. Het is vervolgens aan de rechter in de hoofdzaak om te beoordelen of op grond van art. 843a Rv inzage moet worden verschaft in de in beslag genomen bestanden en ze daarvoor moeten worden ontsleuteld. Anders gezegd, met het beslaan van versleutelde bestanden is het doel van het bewijsbeslag bereikt: het voorkomen dat bewijs verloren gaat. Met het beslaan van een versleutelde hardware wallet is het doel van een conservatoir verhaalsbeslag echter nog niet bereikt. Daarmee wordt immers niet voorkomen dat de bitcoins worden verdonkeremaand en toekomstige executie illusoir wordt. Net zoals de ratio van het bewijsbeslag de Hoge Raad ertoe bracht het bewijsbeslag ook in nietIE-zaken toe te staan en de beslagdebiteur er zelfs toe te verplichten de deurwaarder toegang te verschaffen tot bestanden in de cloud, zo brengt de ratio van het conservatoir verhaalsbeslag met zich dat de beslagdebiteur de code van zijn hardware wallet aan de deurwaarder prijs moet geven, zodat daarmee de bitcoins voor toekomstige executie kunnen worden veiliggesteld.

Anders dan voor het bereiken van het doel van conservatoir verhaalsbeslag op wallets, makt het voor het bereiken van het doel van een bewijsbeslag overigens niet uit of er kopieën (in dit geval: van digitaal bewijs) elders zijn opgeslagen. Zolang er maar één exemplaar van het digitale bewijs wordt beslagen, kan bewijs worden veiliggesteld. Voor het conservatoir verhaalsbeslag ligt dat anders. Juist de mogelijkheid dat er meerdere kopieën van de privésleutel elders kunnen zijn opgeslagen, maakt dat het van groot belang is zo snel mogelijk de beslagdebiteur ertoe te bewegen zijn code tot de hardware wallet prijs te geven. Met behulp daarvan kan immers toegang tot de privésleutel worden verkregen, waarmee de betreffende bitcoins naar een andere bitcoinrekening kunnen worden overgemakkt teneinde ze voor toekomstige executie veilig te stellen. 
Terug naar de aangenomen medewerkingsverplichting. Net zoals in Molenbeek ligt die medewerkingsverplichting mijns inziens in het beslagverlof besloten, omdat de daarin vervatte toestemming tot inbeslagneming anders zinloos zou zijn. Dat neemt niet weg dat het verstandig is die medewerkingsverplichting op voorhand in het beslagrekest te expliciteren en, net zoals voor een bewijsbeslag in de beslagsyllabus is vermeld, de voorzieningenrechter in dat beslagrekest te verzoeken aan het niet onmiddellijk meewerken een ineens te verbeuren dwangsom te verbinden. ${ }^{38}$ Dat voorkomt discussies op de plaats van beslaglegging, waardoor bijvoorbeeld de schuldenaar weigert mee te werken, de schuldeiser zich opnieuw tot de voorzieningenrechter wendt met het verzoek de medewerkingsverplichting te expliciteren, en de schuldenaar in de tussentijd zijn bitcoins alsnog wegsluist.

\section{Executoriaal beslag en executie}

Aannemende dat, op de hiervoor omschreven wijze, conservatoir beslag is gelegd op de paper of hardware wallet en de bitcoins zijn overgemaakt op een door een bank geopende bitcoinrekening, zal de beslaglegger binnen de in het beslagverlof bepaalde termijn een hoofdzaak moeten instellen (art. 700 lid $3 \mathrm{Rv}$, uiteraard tenzij hij al een eis in de hoofdzaak heeft ingesteld). Als de beslaglegger vervolgens een voor tenuitvoerlegging vatbare executoriale titel verkrijgt en aan de beslagdebiteur betekent, gaat het conservatoir beslag automatisch over in een executoriaal beslag (art. 704 lid $1 \mathrm{Rv}$ ). De paper of hardware wallet van de door de bank geopende, nieuwe bitcoinrekening zal dan worden verkocht en de schuldeiser uit de opbrengst daarvan worden voldaan (art. 474a jo. art. 458 jo. art. 463 e.v. Rv). De koper van die nieuwe wallet kan vervolgens, met gebruikmaking van de privésleutel die op de wallet staat, de betreffende bitcoins verkopen. Een interessante vraag die in dat verband rijst, is wat te doen als de te verwachten verkoopopbrengst van de te verkopen paper of hardware wallet (of, beter gezegd, de bitcoins waarover daarmee kan worden beschikt) het bedrag waartoe de schuldenaar is veroordeeld plus kosten zal overstijgen. Art. 470 lid $1 \mathrm{Rv}$ bepaalt: 'Men zal met de verkoop der in beslag genomen zaken niet verder gaan dan nodig is om een opbrengst te verkrijgen, die voor de betaling van de schulden en kosten voldoende is.' Deze bepaling, althans de ratio ervan brengt naar mijn idee met zich dat er voorafgaand aan de executie nieuwe wallets moeten worden aangemaakt, waarnaartoe kleine batches van bitcoins worden overgemaakt. Die wallets met kleine batches kunnen dan achtereenvolgens worden verkocht op zodanige wijze dat er geen of zo min mogelijk executieoverschot is, niet alleen omdat de wet dat voorschrijft, althans veronderstelt, maar ook om discussies te voorkomen met betrekking tot waardefluctuaties tussen het moment van overboeken van het overschot in euro's en het opnieuw daarvan investeren in bitcoins. Vanzelfsprekend zal een desondanks ontstaan executieoverschot alsmede de 'overgebleven' bitcoins moeten worden (terug) overgemaakt naar de schuldenaar.

\section{Conclusie}

Ik concludeer dat conservatoir verhaalsbeslag op bitcoins mogelijk is. Om tot die conclusie te komen doorliep ik de volgende stappen. De al dan niet versleutelde drager waarop de privésleutel staat waarmee over bitcoins kan worden beschikt (de paper of hardware wallet), kan als waardepapier worden gekwalificeerd. Op die drager kan conservatoir verhaalsbeslag worden gelegd. Als de toegang tot de privésleutel is beveiligd met een code, kan de schuldenaar worden gedwongen die code prijs te geven. Met die privésleutel kunnen en moeten de bitcoins worden overgemaakt naar een andere, door een bank of DNB nieuw geopende bitcoinrekening teneinde te voorkomen dat bitcoins aan het beslag (kunnen) worden onttrokken. Zodra de bitcoins zijn overgemaakt op de door de bank of DNB geopende nieuwe bitcoinrekening, komt het conservatoir beslag op de oorspronkelijke paper of hardware wallet door substitutie automatisch te rusten op de nieuwe paper of hardware wallet, dus de wallet van de bank waarin de privésleutel van de nieuwe bitcoinrekening is opgeborgen. Op de paper of hardware wallet van die nieuwe bitcoinrekening komt vervolgens automatisch executoriaal verhaalsbeslag te rusten zodra de schuldeiser een voor tenuitvoerlegging vatbare executoriale titel verkrijgt en aan de schuldenaar betekent. Daarna wordt de nieuwe paper of hardware wallet verkocht en de schuldeiser uit de opbrengst daarvan voldaan.

38. Beslagsyllabus, augustus 2018, p. 57-58 en 60 . 